\title{
Measured performance of exhaust air heat pumps in Finnish apartment buildings
}

\author{
Petri Pylsy ${ }^{1,3^{*}}$, Jarek Kurnitski ${ }^{2,3}$ \\ ${ }^{1}$ The Finnish Real Estate Federation, Annankatu 24, FI-00100, Helsinki, Finland \\ ${ }^{2}$ Tallinn University of Technology, Department of Civil Engineering and Architecture, Ehitajate tee 5, Tallinn, 19086, Estonia \\ ${ }^{3}$ Aalto University, Department of Civil Engineering, Rakentajanaukio 4, FI-02150, Espoo, Finland
}

\begin{abstract}
The energy efficiency of existing apartment buildings is playing an important role in energy and climate targets. In Finland, mechanical exhaust ventilation system is commonly used in older apartment buildings. Hence, there could be an energy saving potential by an exhaust air heat pump system (EAHP). In this work two cases have been studied. Buildings were built in 1960's and 1970's and in renovation equipped with hybrid heating system: district heating and exhaust air heat pump system. Two years measurement data, 2018 and 2019, was collected to evaluate the performance of exhaust air heat pump systems. According to measurement data the monthly coefficient of performance (COP) was calculated as well as seasonal coefficient of performance (SCOP) was defined. The monthly COP values varied from 3,1 to 4,6 and SCOP values were about 3,7. Heating energy cost savings were 23-31\%. Energy performance class before and after EAHP installation was calculated. If at least $50 \%$ of heating energy consumption was covered by EAHP then also energy performance class was improved.
\end{abstract}

\section{Introduction}

The European Commission has proposed that greenhouse emissions should be reduced at least by 55 $\%$ by 2030 in EU [1]. The existing target was $40 \%$ [1]. Also, some national carbon neutrality targets have been set. In Finland the goal of carbon neutrality should be pursued by 2035 [2]. According to the revised energy performance of buildings directive Member States had to create a long-term renovation strategy to decarbonise the building stock by 2050 [3]. In addition, EU commission launched 'Renovation wave' strategy in 2020 [4]. In this strategy one key principle is 'energy efficiency first' and e.g. the possibility of mandatory minimum energy performance standards for existing buildings was mentioned [4]. Thus, it is possible that an Energy Performance Certificate and an energy performance class could be more important for building owners in the future.

The existing building stock will play an important role to achieve climate goals. In apartment buildings an interesting topic is a heat recovery from exhaust air. Finnish apartment buildings are commonly equipped with a mechanical ventilation system since 1960's but buildings built before $21^{\text {st }}$ century a mechanical exhaust ventilation without a heat recovery is typically used [5]. Therefore, ventilation heat losses are normally from 25 $\%$ to $35 \%$ in older apartment buildings [6]. There are two main option to implement the heat recovery from exhaust air: a mechanical supply and exhaust ventilation with heat recovery (HRV) and an exhaust ventilation with exhaust air heat pump (EAHP) [7]. HRV installation is more expensive than EAHP [7] and e.g. in Finland apartment building owners are often more interested in EAHP solutions. Rämä et al. [8] evaluated EAHPs potential in Finland and presented that EAHP solutions could reduce district heating energy consumption by $2,7 \mathrm{TWh}$ and increase electricity consumption by $0,8 \mathrm{TWh}$ in a long run.

Building owners as well as EAHP system planners need reliable information about the performance of EAHP system. There are some studies about the EAHP systems in apartment buildings. Gustafsson et al. [9] studied by simulations energy renovation measures of apartment building including different kind of EAHP systems. Seasonal performance factors of EAHP varied from 4,55 to 6,13 and heating demand covered by the heat pump from $35 \%$ to $49 \%$ [9]. Gustafsson et al. [10] studied a semi-detached single-family house with EAHP and according to performance data for an existing air-towater heat pump COP values varied from 3,3 to 5,4 . Mikola \& Kõiv [11] studied a new apartment building built in 2011 and measurements pointed out that in that case the coefficient of performance (COP) was about 2,9-3,4 in winter and 3,0 in summer. Rämä et al [8] studied 13 EAHP cases in Finnish apartment buildings built in 1960s-1990s. In these cases, COPs were between 2,0 and 4,5 and commonly around 3,5. Rämä et al. also reported that the quality of measurement data varied and almost in $40 \%$ of cases heat pump electricity consumption was estimated, so not based on exact measurement result.

Therefore, there is a need for long term monitoring studies focusing on older apartment buildings. In this

\footnotetext{
* Corresponding author: petri.pylsy@,kiinteistoliitto.fi, petri.pylsy@aalto.fi
} 
case study two exhaust air heat pump system were studied according to two years measurement data. Monthly COPs as well as seasonal performance of coefficient (SCOP) are defined. Calculated SCOPs are used to calculate EAHP effect on an energy performance class.

\section{Materials and Methods}

\subsection{Case buildings}

Case buildings (Case A and Case B, Table 1) are located in Finland, City of Jyväskylä. The monthly average outdoor temperature of Jyväskylä is shown in Fig. 1. Apartment buildings were built in 1960's (Case A) and 1970's (Case B). In both cases central heating is utilized, and the original heating system was district heating and the ventilation system was centralized mechanical exhaust ventilation. In renovation Case A and $\mathrm{B}$ were both equipped with a hybrid heating system: district heating with exhaust air heat pump system.

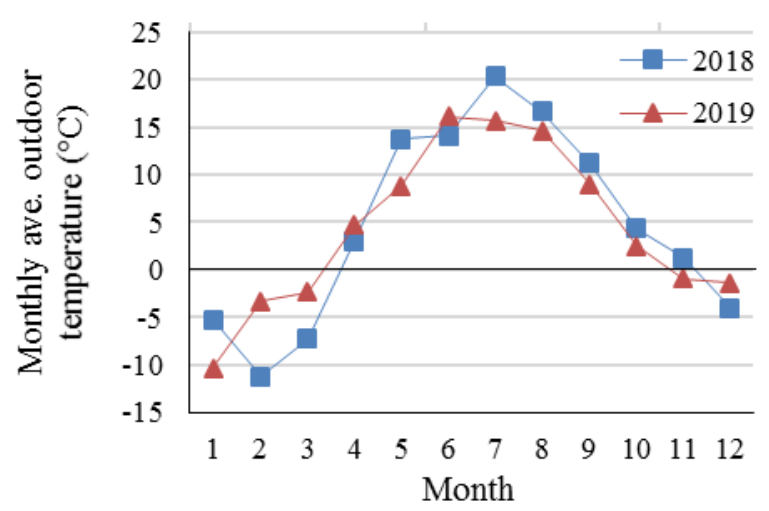

Figure 1. The monthly average outdoor temperature in Jyväskylä 2018 and 2019 [12].

Table 1. Description of Case A and B.

\begin{tabular}{|c|c|c|}
\hline & Case A & Case B \\
\hline Year of construction & 1963 & 1973 \\
\hline Number of buildings & 1 & 2 \\
\hline Number of dwellings & 46 & 26 \\
\hline Building volume $\left[\mathrm{m}^{3}\right]$ & 11025 & 8761 \\
\hline Net heated floor area $\left[\mathrm{m}^{2}\right]$ & 3448 & 2746 \\
\hline Number of stories & 5 & 5 \\
\hline
\end{tabular}

\subsection{EAHP systems}

The EAHP system was started up Apr 2015 (Case A) and Dec 2014 (Case B). In both cases the system consists of a heat pump, two heat recovery unit with fan (on the roof) and a hot water storage tank for preheating domestic hot water $\left(500 \mathrm{dm}^{3}\right)$. The heat pump was equipped with two units (EP15 and EP14) and a nominal heat output was $30 \mathrm{~kW}$ and $20 \mathrm{~kW}$ in Case A and B respectively. EP15 produce only heat for radiators. EP14 can produce heat either for DHW or radiators and this was controlled by a motorized 3-way valve. 3-way valve was controlled according to the hot water tank temperature: Temperature set points were (min; start) 40 ${ }^{\circ} \mathrm{C}$ and (max; stop) $45^{\circ} \mathrm{C}$ in Case $\mathrm{A}$ and $45^{\circ} \mathrm{C} / 50{ }^{\circ} \mathrm{C}$ in case B. The setpoints for delivery of DHW were 55-58 ${ }^{\circ} \mathrm{C}$.-

The heating characteristic curve of heat pump for space heating is shown in Fig. 2 as a function of outdoor temperature.

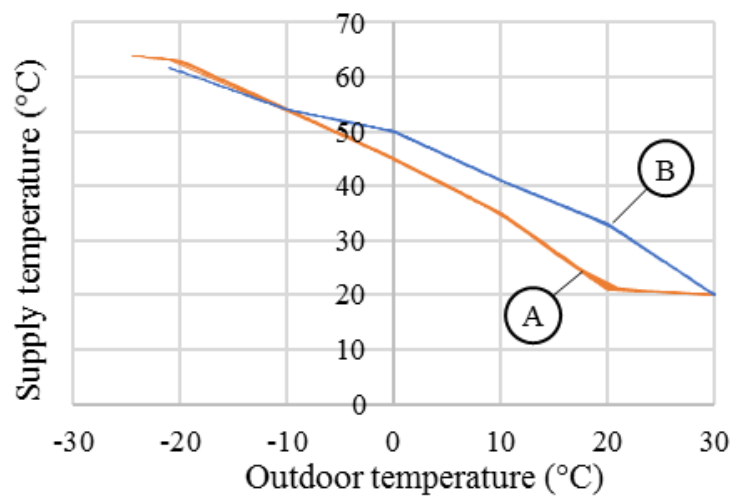

Figure 2. Heating characteristic curves (A: Case A; B: Case B)

Exhaust ventilation equipped with variable speed drive was controlled by a time schedule and an outdoor temperature. In both cases at the building level an exhaust air flow was increased three times per day (enhanced periods): 7:30-9:30, 16:30-18:30 and 20:3022:30. The exhaust air flow was also controlled according to the outdoor temperature: in the wintertime fan speed was reduced compared to the summertime. In case A a speed control range was from $30 \%$ to $40 \%$ and from $45 \%$ to $58 \%$ during a normal use and enhanced use respectively. In Case B the range was from $30 \%$ to $50 \%$ in normal use and from $45 \%$ to $65 \%$ in enhanced use.

The heat pump and a district heating substation were connected in parallel. An EAHP connection scheme was same in both cases and is shown in Fig. 3.

\subsection{The coefficient of performance}

Two years measurement data, 2018 and 2019, was collected to evaluate the performance of EAHP. Heat produced for space heating $\left(Q_{H P, s}\right)$ and domestic hot water $\left(Q_{H P, d h w}\right)$ by EAHP as well as electricity consumption of EAHP $\left(P_{H P}\right)$ and district heating energy consumption $\left(Q_{D H}\right)$ was measured by building 


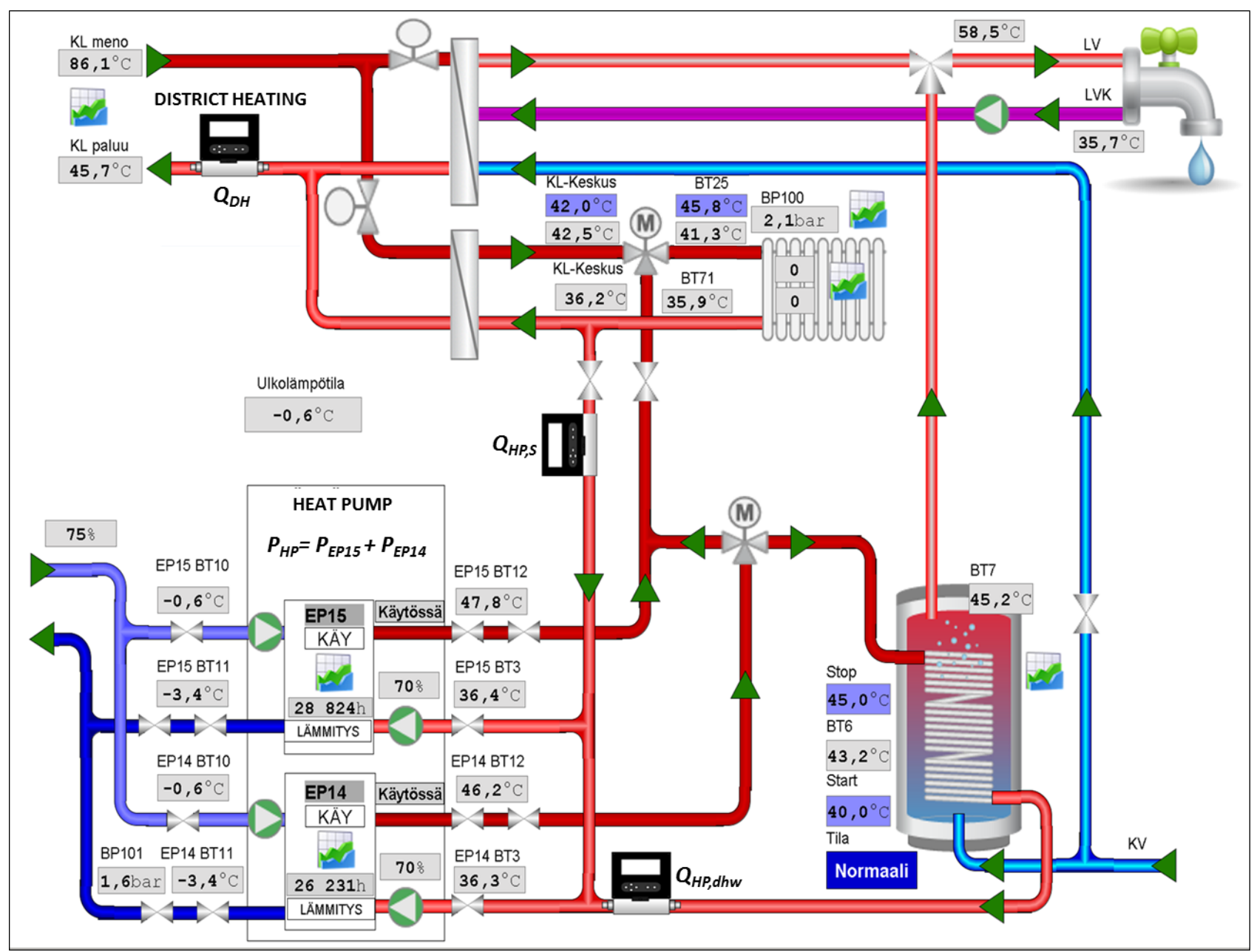

Figure 3. Exhaust air heat pump connection scheme which is similar in Case A and B.

automation system (BAS). Measurement points (devices) are shown in Fig. 3. According to measurement data the monthly coefficient of performance $\left(C O P_{m}\right)$ and the seasonal coefficient of performance $(S C O P)$ were calculated according Eq. (1) and Eq. (2).

$$
\begin{gathered}
C O P_{m}=\left(Q_{H P, s, m}+Q_{H P, d h w, m}\right) / P_{H P, m} \\
S C O P=\Sigma\left(Q_{H P, s, m}+Q_{H P, d h w, m}\right) /{ }_{\Sigma} P_{H P, m}
\end{gathered}
$$

\subsection{Energy performance class and energy savings}

A energy performance reference value (E-value, $\mathrm{kWh}_{\mathrm{E}} / \mathrm{m}^{2} / \mathrm{a}$ ) and energy performance classes were calculated according to Finnish Decree of the Ministry of the Environment on Energy Performance Certificates of Buildings [13]. The E-value is a building's calculated annual consumption of delivered energy weighted by energy carrier factors per the building's net heated area. The energy carrier factor is 0,5 for district heating and 1,2 for electricity [14]. Calculated delivered energy based on the building's standardised use according to ref. [13]. In Finland the energy performance class is defined according the E-value [13]. The E-value can be understood as a primary energy approximation.

Table 2. Description of building envelope.

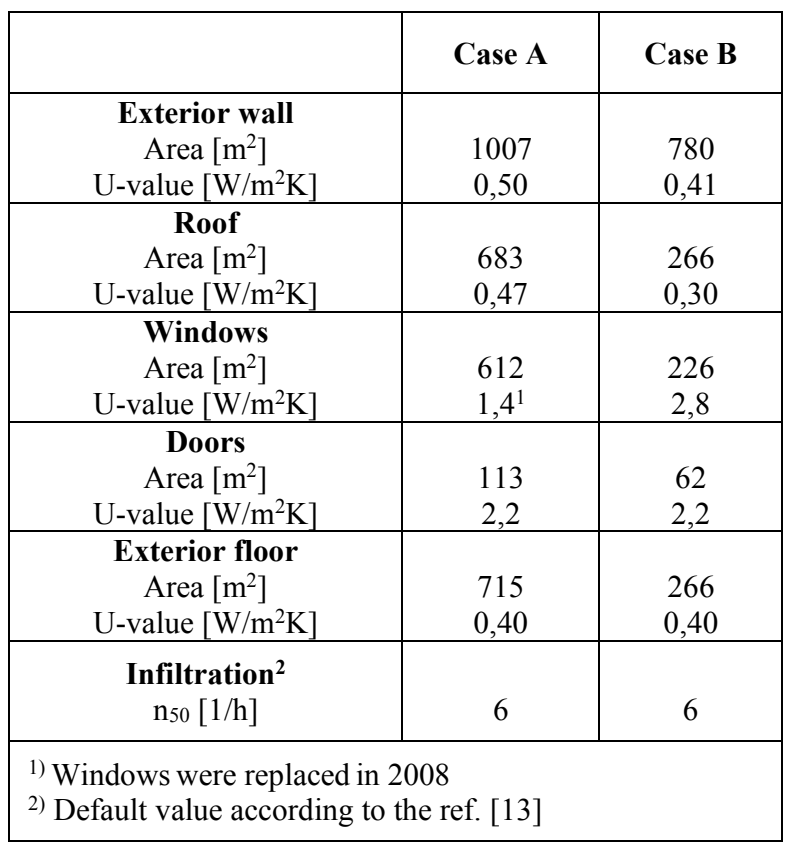


Calculation tool Laskentapalvelut.fi [15] was used to calculate E-values and energy performance classes. Calculation tool based on a monthly method and fulfils requirements of ref [13]. In Table 2 is shown description of building envelope in the energy performance class calculations. Calculated SCOPs were utilized in the Evalue calculations.

An estimate of heating energy costs (HEC) was calculated (Eq. 3) and average electricity $\left(H_{e}\right)$ and district heating $\left(H_{D H}\right)$ prices of Jyväskylä was used. Prices based on Indeksitalo 2020 calculation by Finnish Real Estate Federation [16]. An average electricity price was $130 € / M W h(V A T 24 \%$ ). A district heating energy price was $58 € / \mathrm{MWh}$ (VAT $24 \%$ ) and an average selling price was $84 € / M W h$ (VAT $24 \%$ ). The average selling price includes also fixed annual fees which commonly based on a heating peak power.

$$
H E C=Q_{D H} * H_{D H}+P_{H P} * H_{e}
$$

Measured average values for $Q_{D H}$ and $P_{H P}$ was used in energy cost calculations.

\section{Results and discussion}

\subsection{The performance of exhaust air heat pump system}

Heat produced by EAHP for space heating and domestic hot water is shown in Fig. 4 when Case A is considered. During a winter DHW production was approximately $34 \%$ of total EAHP heat production and during a summer $66 \%$. A raising question is why the heat was produced by EAHP for space heating in the summer. It should be also noticed that during the winter heat produced for DHW was almost three times bigger than summer.

In Fig. 5 is shown district heating energy consumption and electricity consumption of EAHP. Approximately $54 \%$ of annual heating energy consumption $\left(Q_{H P, s}+Q_{H P, d h w}+Q_{D H}\right)$ was covered by EAHP production. During a spring and an autumn, the share of production was the highest, over $65 \%$.

In Case A the monthly COPs are shown in Fig. 6. In summertime COP is higher because DHW production was dominant and therefore heat pump supply temperature levels are lower than wintertime. The SCOP of case A was 3,78 and 3,68 in 2018 and 2019 respectively.

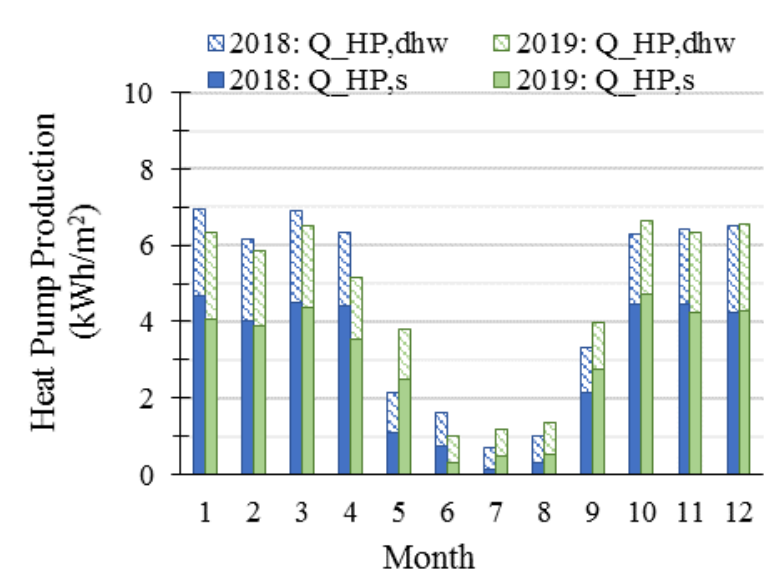

Figure 4. Heat produced by EAHP (QHP,s: space heating; QHP,dhw: DHW), Case A

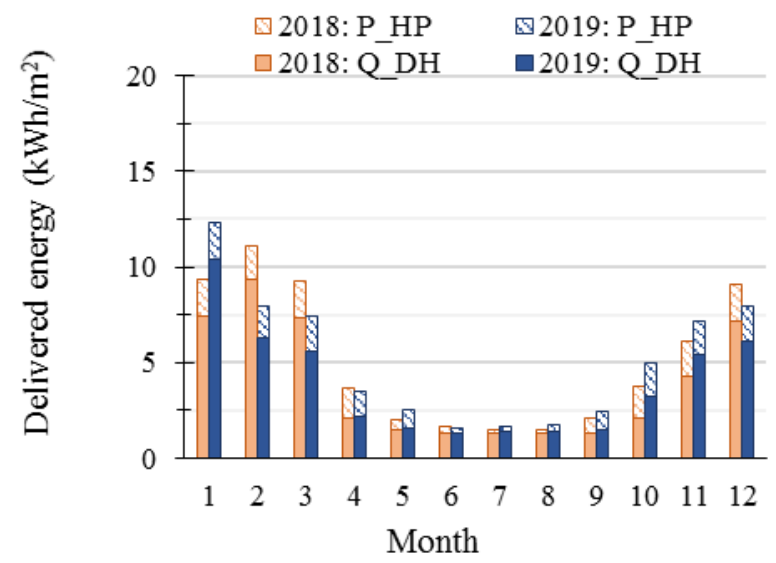

Figure 5. Delivered energy: district heating $\left(\mathrm{Q}_{\mathrm{DH}}\right)$ and the electricity consumption of EAHP (РнP), Case A

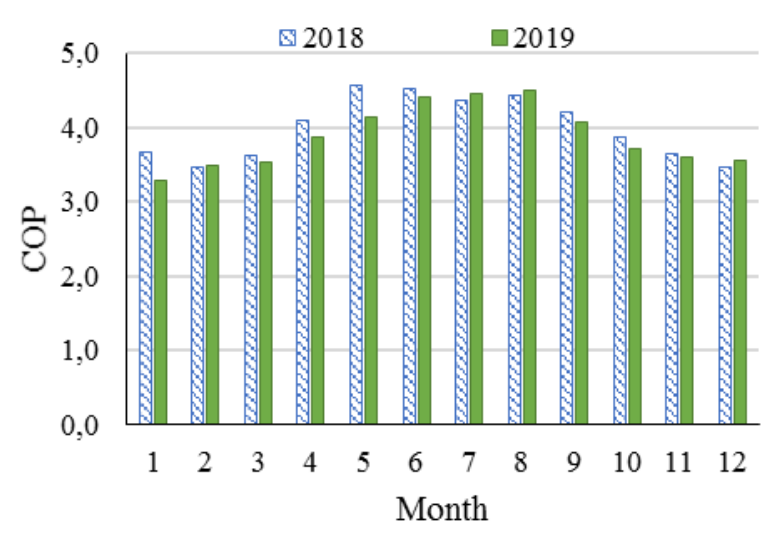

Figure 6. Monthly COP, Case A 


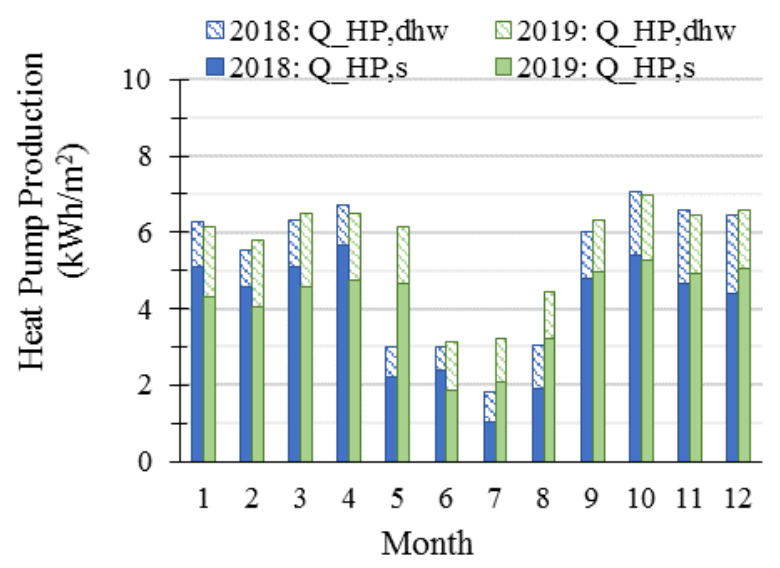

Figure 7. Heat produced by EAHP (QHР,s: space heating; QHP,dhw: DHW), Case B

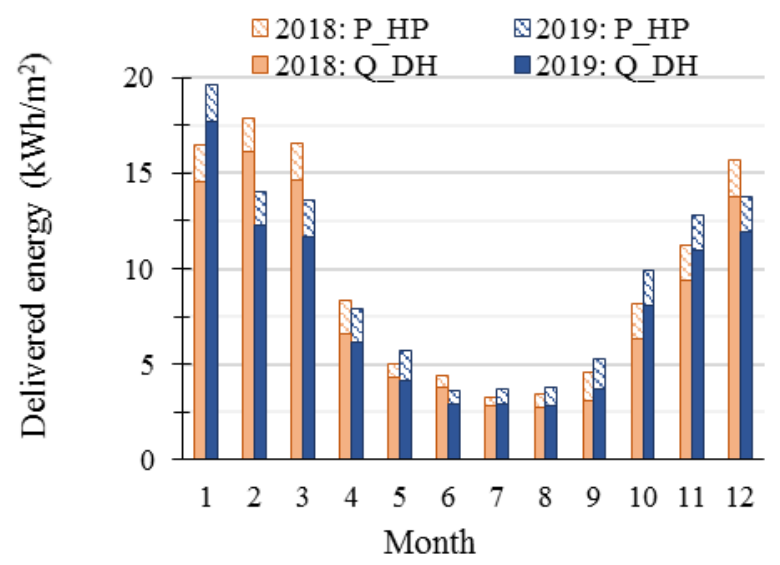

Figure 8. Delivered energy: district heating $\left(\mathrm{Q}_{\mathrm{DH}}\right)$ and the electricity consumption of EAHP (РнР), Case B

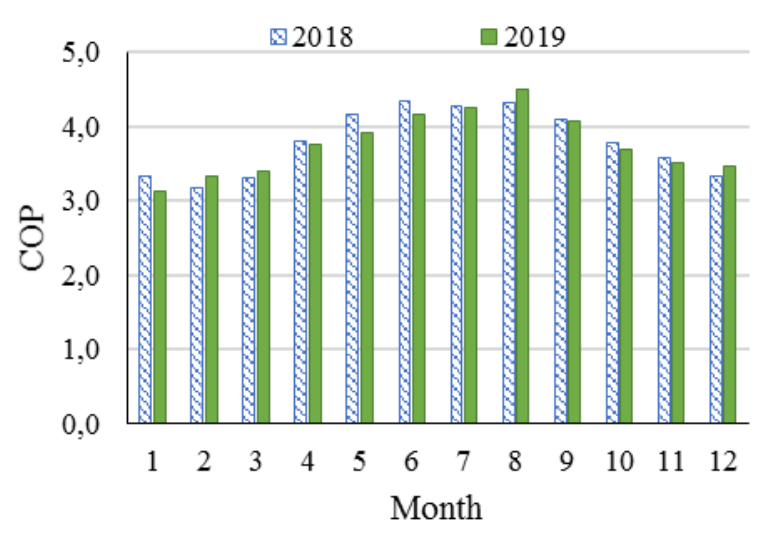

Figure 9. Monthly COP, Case B

When Case B is considered DHW production was about $24 \%$ of total EAHP heat production during the winter and $34 \%$ during the summer (Fig. 7). A reason for the rather high share of space heating during the summer could be a swimming pool inside the building. In Fig. 8 is shown monthly delivered energy for heating. About $40 \%$ of annual heating energy consumption was covered by EAHP in Case B. Also, in Case B monthly COP values were higher in the summer than in the winter (Fig. 9). SCOP values were 3,65 and 3,67 in 2018 and 2019 respectively.
When Case A and B are compared it can be noticed that monthly COPs as well as SCOP values are close to each other even if there was a difference between the heating characteristic curves. When the share of heating energy produced by EAHP was compared there was a quite significant difference between Case A and B. In Case A the share was almost $55 \%$ but in Case B only $40 \%$. More detailed data analysis should be done and also e.g. mechanical ventilation air flow rates, the operation of heat recovery units and the heat pump dimensioning should taken into account more closely in future studies. Of course, also difference in heating demand between Case A and B should be taken into account. E.g. in Case A the thermal transmittance of windows was better than in Case B.

When Case A and B are compared with earlier studies [8], [9] and [11] some differences can be seen. When COPs according to [11] is compared to this study it should be noticed that during summer Case A and B provide higher COPs than ref. [11]. A reason for that could be a different connection scheme type and control strategy of EAHP. Gustafsson et al. [9] reported much higher simulated seasonal performance than this study. One reason could be lower supply temperatures of heat pump. Therefore, more detailed analysis should be done concerning supply temperature and its effect on measured COPs. Also, simulation models and measured cases should be compared more carefully in the future work.

\subsection{EAHP effect on E-value, energy performance class and energy savings}

Calculated E-values and energy performance classes for district heating case (DH) and district heating with EAHP (DH+EAHP) is shown in Table 3. In calculations the SCOP of EAHP was according to results shown in Chap. 3.1 as well as the share of heating energy produced by EAHP.

EAHP reduce the E-value by $20 \%$ and $15 \%$ in Case $A$ and $B$ respectively. Also, the energy performance class would be improved from $\mathrm{F}$ to $\mathrm{E}$ when Case $\mathrm{A}$ is considered. In case B the energy performance class remains unchanged. Thus, changes in the EP class is also dependent on an overall initial situation. If $50 \%$ of heating energy consumption was produced by EAHP in Case B then the E-value would be reduced by $18 \%$ and the EP class would be E.

In Finland The Housing Finance and Development Centre of Finland (ARA) grants a subsidy for an energy renovation project if E-value will be reduced enough [17]. When apartment buildings are considered the Evalue must be reduced by $32 \%$ compared to the E-value of the year of construction to fulfil the criteria [16]. In both cases only the EAHP system would not be enough to fulfil the E-value requirement of subsidy. In Case A e.g. the building envelope should be renovated (e.g. $n_{50}$ $2,0 \mathrm{~h}^{-1}$ and the thermal transmittance of exterior wall $0,25 \mathrm{~W} / \mathrm{m}^{2} \mathrm{~K}$ ) to achieve the E-value target. Also, in Case $B$ if the building envelope was renovated (e.g. $\mathrm{n}_{50}$ $2,0 \mathrm{~h}^{-1}$ and the thermal transmittance of windows 0,8 
$\mathrm{W} / \mathrm{m}^{2} \mathrm{~K}$ ) then a renovation package would manage to reduce the E-value by $32 \%$.

Table 3. E-value $\left(k W h_{E} / m^{2} / a\right)$, energy performance class ( $E P$ class $)$, district heating energy consumption $\left(Q_{D H}, \mathrm{kWh} / \mathrm{m}^{2} / a\right)$, EAHP electricity consumption $\left(P_{H P}, k W h / \mathrm{m}^{2} / a\right)$ and heating energy costs $(H E C, € / a)$ for DH case and DH+EAHP case

\begin{tabular}{|c|c|c|c|c|c|}
\hline & $\begin{array}{c}\text { E- } \\
\text { value }^{3}\end{array}$ & $\begin{array}{c}\mathbf{E P} \\
\text { class }\end{array}$ & $Q_{\text {DH }}$ & $\mathbf{P}_{\mathbf{H P}}$ & HEC $^{4}$ \\
\hline \multicolumn{6}{|l|}{ CASE $\mathbf{A}^{1}$} \\
\hline DH & 198 & F & 101 & 0 & 29253 \\
\hline DH+EAHP & 164 & E & 46 & 15 & 20047 \\
\hline \multicolumn{6}{|l|}{ CASE B ${ }^{2}$} \\
\hline DH & 228 & $\mathrm{~F}$ & 162 & 0 & 37368 \\
\hline $\mathrm{DH}+\mathrm{EAHP}$ & 198 & $\mathrm{~F}$ & 97 & 18 & 28800 \\
\hline \multicolumn{6}{|c|}{$\begin{array}{l}\text { 1) SCOP } 3,7 \text { and } 54 \% \text { of heating energy was produced by } \\
\text { EAHP } \\
\text { 2) SCOP } 3,7 \text { and } 40 \% \text { of heating energy was produced by } \\
\text { EAHP } \\
\text { 3) In E-value calculations other electricity consumption } \\
\text { was } 35 \mathrm{kWh} / \mathrm{m}^{2} / \mathrm{a} \text { and } 33 \mathrm{kWh} / \mathrm{m}^{2} / \mathrm{a} \mathrm{DH} \text { case and } \\
\mathrm{DH}+\mathrm{EAHP} \text { case respectively } \\
\text { 4) DH+EAHP: Average selling price was used. If district } \\
\text { heating energy price was used, then HEC would be } \\
24977 € \text { and } 33441 € \text { in Case A and Case B respectively }\end{array}$} \\
\hline
\end{tabular}

Calculated energy costs according to measurement data is also shown Table 3. Estimated heating energy cost saving was about $31 \%$ and $23 \%$ in Case A and B respectively when the average district heating selling price was considered. A typical investment cost could be about $80000-120000 €$ thus a payback period could be 8-13 years in Case A and 9-14 years in Case B. When simplified calculations are done and the average district heating selling price is utilized it contains an assumption that EAHP effect also on annual fixed fees. If EAHP effect only on an annual district heating energy costs (the district heating energy price) then heating cost saving would be only $15 \%$ and $11 \%$ in Case A and Case $\mathrm{B}$ respectively and payback periods would be about 1,52 times higher. Thus, financial feasibility highly depends on changes in fixed fees of district heating and therefore optimizing EAHP is not only a question about delivered energy but also peak heating power (at design outdoor air temperature). Therefore, in investment cost calculation should be taken into account real district heating and electricity price components and use of any average values should be avoided.

\section{Conclusion}

This paper evaluated the performance of exhaust air heat pump system in Nordic climate. The evaluation was based on the measurement data of two cases and monthly COP and SCOP was calculated. Also, EAHP effect on the energy performance class and the energy cost was studied. The following conclusion can be drawn:

- Monthly COP values varied from 3,1 to 4,6. The highest value was achieved in the summer and the lowest in the winter.

- SCOP value was about 3,7.

- Approximately $54 \%$ of annual heating energy consumption was covered by EAHP production in Case A and $40 \%$ in Case B. This revealed to be a remarkable difference when energy performance class as well as energy costs were considered.

- Primary energy (E-value) was reduced by 15-20 $\%$.

- The energy performance class was improved if EAHP covered more than $50 \%$ of annual heating energy consumption.

- Heating energy cost savings were 23-31\% when average district heating selling price was considered.

- Financial feasibility was highly depending on changes in fixed fees of district heating and therefore real and local energy price components must be used in investment cost calculations.

- In EAHP system planning, also the effect on heating peak power must be taken into account.

- While good potential of EAHP systems was demonstrated by measured performance, more detailed analysis would be needed to improve and optimize the operation of systems as well as to generalize results to be more be representative when apartment building stock is considered.

This research was supported with the grant from K.V. Lindholms Stiftelse foundation and Säätiö L.V.Y . foundation and by the Academy of Finland (grant for DECARBON-HOME 335253), by the Estonian Centre of Excellence in Zero Energy and Resource Efficient Smart Buildings and Districts, ZEBE, grant 20142020.4.01.15-0016 funded by the European Regional Development Fund and by the European Commission through the H2020 project Finest Twins (grant No. 856602).

\section{References}

[1] European Commission, 2030 Climate Target Plan.[Online]. Available :

https://ec.europa.eu/clima/policies/eu-climateaction/2030_ctp_en. [Accessed:17 Jan 2021]

[2] Programme of Prime Minister Sanna Marin's Government 10 December 2019. Inclusive and competent Finland - a socially, economically and ecologically sustainable society. Publications of the Finnish Government 2019:33. Available : 
https://julkaisut.valtioneuvosto.fi/handle/10024 $/ 161935$

[3] Directive 2018/844/EU of the European Parliament and the Council of 30 May 2018 amending Directive 2010/31/EU on the energy performance of buildings and Directive 2012/27/EU on energy efficiency. Off. J. Eur. Union 2018. L156/75, 19.06.

[4] European Commission, A Renovation Wave for Europe - Greening our buildings, creating jobs, improving lives,.[Online]. Available: https://eur-lex.europa.eu/legalcontent/EN/TXT/HTML/?uri=CELEX:52020D C0662\&from $=$ EN. [Accessed 17 Jan 2021]

[5] Rakennustieto, RT56-10831 Asuinrakennuksen ilmanvaihtojärjestelmän peruskorjaus ja parannus, 2004.

[6] J. Virta, P. Pylsy, Taloyhtiön energiakirja, Kiinteistöalan Kustannus, 2011

[7] M. Thalfeldt, J. Kurnitski, E. Latõšov, Exhaust air heat pump connection schemes and balanced heat recovery ventilation effect on district heat energy use and return temperature, App. Therm. Eng. 128 (2018) 402-414.

[8] M. Rämä, R. Niemi, L. Similä, Poistoilmalämpöpumput kaukolämpöjärjestelmässä, Asiakasraportti VTT-CR-00564-15. VTT, 2015.

[9] M. Gustafsson, M.S. Gustafsson, J.A. Myhren, C. Bales, S. Holmberg, Technoeconomic analysis of energy renovation measures for a district heated multifamily house, Appl. Energy 177 (2016) 108-116.

[10] M. Gustafsson, G. Dermentzis, J. A. Myhren, C. Bales, F. Ochs, S. Holmberg, W. Feist, Energy performance comparison of three innovative HVAC systemsfor renovation through dynamic simulation, Energy and Buildings 82 (2014) 512-519.

[11] A. Mikola, T.-A. Kõiv, The efficiency analysis of the exhaust air heat pump system, Engineering 6 (2014) 1037-1045.

[12] The Finnish Meteorological Institute's open data. Outdoor temperature, Jyväskylä 20182019. [Online]. Available: https://www.ilmatieteenlaitos.fi/havaintojenlataus. [Accessed 17 Jan 2021]

[13] 1048/2017 Decree of the Ministry of the Environment on Energy Performance Certificates of Buildings. The Ministry of the Environment of Finland, 2017.

[14] $788 / 2017$ Government Decree on the numerical values of coefficients for forms of energy used in buildings. The Finnish Government, 2017.

[15] Laskentapalvelut.fi calculation tool [Online]. Available: https://www.laskentapalvelut.fi. [Accessed 17 Jan 2021]

[16] Finnish Real Estate Federation, Indeksitalo 2020 [Online]. Available: https://www.kiinteistoliitto.fi/palvelut/tutkimus /saannolliset/indeksitalo/ [Accessed 17 Jan 2021]
[17] Energy renovation subsidies, The Housing Finance and Development Centre of Finland (ARA) [Online]. Available:

https://www.ara.fi/fi-

FI/Lainat_ja_avustukset/Energiaavustus/Taloy htiot. [Accessed 17 Jan 2021] 